ISSN 1678-3921

Journal homepage: www.embrapa.br/pab

For manuscript submission and journal contents, access: www.scielo.br/pab

\author{
Alexandre Passos Oliveira ${ }^{(1 凶)}(\mathbb{D}$, \\ Pryanka Thuyra Fontes ${ }^{(1)}(1)$, \\ Laila Beatriz Santos Maciel(1) (iD), \\ Jailson Lara Fagundes(2) (D), \\ Marcelo Augusto Gutierrez \\ Carnelossi(3) (iD) and \\ Luiz Fernando Ganassali de Oliveira \\ Júnior $^{(1)}$ (iD) \\ (1) Universidade Federal de Sergipe, \\ Departamento de Engenharia Agronômica, \\ Avenida Marechal Rondon, s/no, Jardim \\ Rosa Elze, CEP 49100-000 São Cristóvão, \\ SE, Brazil. \\ E-mail: tande1992@gmail.com \\ pryankafontes@yahoo.com.br, \\ laila.bsm1@gmail.com, \\ lfg.ufs@gmail.com \\ (2) Universidade Federal de Sergipe, \\ Departamento de Zootecnia, Avenida \\ Marechal Rondon, s/no , Jardim Rosa Elze, \\ CEP 49100-000 São Cristóvão, SE, Brazil. \\ E-mail: ratinhojlf@yahoo.com.br \\ (3) Universidade Federal de Sergipe, \\ Departamento de Tecnologia de Alimentos, \\ Avenida Marechal Rondon, s/no, Jardim \\ Rosa Elze, CEP 49100-000 São Cristóvão, \\ SE, Brazil. \\ E-mail: magcarnelossi@oi.com.br \\ $\bowtie$ Corresponding author
}

Received

January 30, 2020

Accepted

February 15, 2021

How to cite

OLIVEIRA, A.P.; FONTES, P.T.; MACIEL, L.B.S.; FAGUNDES, J.L.; CARNELOSSI, M.A.G.; OLIVEIRA JÚNIOR, L.F.G. de. Physiological performance, bromatological quality, and productivity of sweet potato using calcium oxide particle film. Pesquisa Agropecuária Brasileira, v.56, e01789, 2021. DOI: https://doi. org/10.1590/S1678-3921. pab2021.v56.01789.

\section{Physiological performance, bromatological quality, and productivity of sweet potato using calcium oxide particle film}

\begin{abstract}
The objective of this work was to evaluate the effect of the application of calcium oxide $(\mathrm{CaO})$ particle film on the physiological performance, bromatological quality, and productivity of sweet potato (Ipomoea batatas). The experimental design was randomized complete blocks with three treatments $(5,10$, and $15 \% \mathrm{CaO}$ particle film concentrations) and a control (water), with three replicates, applied 30 days after planting. The following parameters were evaluated: physiological, including net photosynthetic rate and Falker chlorophyll index (FCI); bromatological, i.e., crude protein, neutral detergent fiber (NDF), acid detergent fiber (ADF), total digestible nutrients (TDN), dry matter digestibility (DMD), and total carbohydrates; and productivity. The use of the 10 and $15 \% \mathrm{CaO}$ particle film increased sweet potato photosynthesis, FCI, crude protein content, and tuber and aerial part productivity. At those concentrations, the lowest NDF and ADF contents and the highest TDN and DMD contents were also observed. The use of the $\mathrm{CaO}$ particle film at the concentration of 10 and $15 \%$ improves the physiological, productivity, and bromatological parameters of the sweet potato crop.
\end{abstract}

Index terms: Ipomoea batatas, animal feeding, calcium oxide, productivity.

\section{Desempenho fisiológico, qualidade bromatológica e produtividade da batata-doce com uso de filme de partícula de óxido de cálcio}

Resumo - O objetivo deste trabalho foi avaliar o efeito da aplicação de filme de partículas de óxido de cálcio $(\mathrm{CaO})$ no desempenho fisiológico, na qualidade bromatológica e na produtividade da batata-doce (Ipomoea batatas). O delineamento experimental foi em blocos ao acaso, com três tratamentos (5, 10 e $15 \%$ de concentração do filme de partículas de $\mathrm{CaO})$ e controle (água), com três repetições, aplicados 30 dias após o plantio. Foram avaliados os seguintes parâmetros: fisiológicos, incluindo taxa fotossintética líquida e índice de clorofila de Falker (ICF); bromatológicos, isto é, proteína bruta, fibra em detergente neutro (FDN), fibra em detergente ácido (FDA), nutrientes digestíveis totais (NDT), digestibilidade da matéria seca (DMS) e carboidratos totais; e produtivos. O uso de filme de partículas de $\mathrm{CaO}$, nas concentrações de 10 e $15 \%$, aumentou a fotossíntese, o ICF, o conteúdo de proteína bruta, e a produtividade das raízes e das brotações da batata-doce. Nessas concentrações, também foram observados os menores teores de FDN e FDA e os maiores teores de NDT e DMS. O uso do filme de partículas à base de $\mathrm{CaO}$, nas concentrações de 10 e $15 \%$, promove melhoria dos atributos fisiológicos, produtivos e bromatológicos da cultura da batata-doce.

Termos para indexação: Ipomoea batatas, alimentação animal, óxido de cálcio, produtividade. 


\section{Introduction}

Sweet potato [Ipomoea batatas (L.) Lam.] is an essential tuberous root, which has multiple uses, such as animal feed, ethanol production, and, especially in developing countries, human food (Drapal et al., 2019; Silva et al., 2019a). However, the most common use is for tuber production, and the aerial part (branches and leaves) is discarded or destined to feed cattle (Backer et al., 1980; Akoetey et al., 2017).

Sweet potato branches - due to their abundant aerial part, with a large number of succulent stems - are also an essential source of food for pigs that can be supplied as green fodder or silage (Monteiro et al., 2007; Corrêa et al., 2016). According to Aregheore (2004), some varieties of sweet potato have a potential of producing between 4.0 and $6.0 \mathrm{Mg} \mathrm{ha}^{-1}$ dry matter (DM), of which approximately $64 \%$ comprises the aerial part (leaves, petiole, and stem).

In general, the bromatological composition of sweet potato branches is highly satisfactory, which makes them an alternative food for animals, particularly due to their high yield, palatability (higher than $62 \%$ ), and crude protein content (from 11 to 17\%) (Aregheore, 2004). In addition, these characteristics, associated with a high moisture content, make sweet potato branches a suitable protein supplement for animals that receive low-quality forage in the dry season (Thibodeau et al., 2002).

However, sweet-potato productivity and bromatological composition may be affected by adverse climatic conditions, even though the species is adapted to regions with low rainfall patterns and water availability. The effects on sweet potato may include: changes in cell wall structure; restriction of stomatal opening, affecting the photosynthetic system of the plants; and an increase in tissue lignification, reducing the protein content of leaves (Velásquez et al., 2010; Ravi \& Saravanan, 2012; Delazari et al., 2017). With the reduction of photosynthesis, the production of carbohydrates, which could be stored by plants for use during their development, also decreases (Ravi \& Saravanan, 2012; Delazari et al., 2017).

One of the alternatives to promote the protection of aerial plant parts, reducing the damage caused to leaf tissue structures, is the application of a particle film. Studies have shown the effects of particle film on the anatomical characteristics of leaves. One that stands out is the reduction of leaf tissue and, consequently, the relationship between palisade and foamy parenchyma, an indicative of a less compact arrangement of mesophilic cells, contributing to the maintenance of the structural and chemical composition of leaves, which improves photosynthesis efficiency (Bacelar et al., 2009; Segura-Monroy et al., 2015; Brito et al., 2018, 2019a).

The objective of this work was to evaluate the effect of the application of calcium oxide particle film on the physiological performance, bromatological quality, and productivity of sweet potato.

\section{Materials and Methods}

Sweet potato was cultivated at the experimental farm of Universidade Federal do Sergipe, located in the municipality of São Cristovão, in the state of Sergipe, Brazil (10 $55^{\prime} 27^{\prime \prime} \mathrm{S}, 37^{\circ} 12^{\prime} 01^{\prime \prime} \mathrm{W}$, at an altitude of $\left.46 \mathrm{~m}\right)$. According to Köppen, the climate is classified as, tropical rainy, with an average annual temperature of $25.2^{\circ} \mathrm{C}$ (dry summer) and precipitation of $1,300 \mathrm{~mm}$, mostly from April to September (Santos et al., 2009). The soil of the experimental area is classified as an Argissolo Vermelho-Amarelo (Santos et al., 2018), i.e., an Ultisol according to Soil Taxonomy (Soil Survey Staff, 1999), which is typical of the Brazilian coastal plains (Oliveira et al., 2017), showing the following chemical properties: $\mathrm{pH}\left(\mathrm{H}_{2} \mathrm{O}\right) 5.49,18.04 \mathrm{mg} \mathrm{L}^{-1} \mathrm{P}$, $82.20 \mathrm{mg} \mathrm{dm}^{-3} \mathrm{~K}, 2.00 \mathrm{cmol}_{\mathrm{c}} \mathrm{kg}^{-1} \mathrm{Ca}, 1.00 \mathrm{cmol}_{\mathrm{c}} \mathrm{kg}^{-1} \mathrm{Mg}$, $2.54 \mathrm{cmol}_{\mathrm{c}} \mathrm{kg}^{-1} \mathrm{H}+\mathrm{Al}$, base saturation of $45.43 \%$, cation exchange capacity at $\mathrm{pH} 7.0$ of $6.45 \mathrm{cmol}_{\mathrm{c}} \mathrm{dm}^{-3}$, and $2.67 \mathrm{dag} \mathrm{kg}^{-1}$ organic matter.

The experimental design was randomized complete blocks, with the application of three calcium oxide $(\mathrm{CaO})$ particle film concentrations $(5,10$, and $15 \%)$ and a control (water). Each experimental unit consisted of one plant, totaling four replicates per treatment. The planting lines consisted of $18 \mathrm{~m}$ long $\times 0.6 \mathrm{~m}$ wide ridges, spaced $0.3 \mathrm{~m}$ between plants and $1.0 \mathrm{~m}$ between ridges. Borders were used on the sides of the experiment, where the same sweet potato cultivar evaluated was planted.

The $\mathrm{CaO}$ particle film was applied from 30 days after planting (DAP) until harvest. The film had a bright white color, with a reflectance close to or higher than $90 \%$, a particle size of $\leq 2.0 \mu \mathrm{m}$, and a uniform distribution due to the constant pressure and flow rate used, promoting full-leaf coverage during its application. The concentrations used were 5, 10, 
and $15 \% \mathrm{CaO}$ and water (control). The UX620H semi-analytical balance (Shimadzu Corporation, Kyoto, Japan) was used to obtain the weight of $\mathrm{CaO}$, to which distilled water was added afterwards. The film was applied whenever its luminosity $\left(\mathrm{L}^{*}\right)$ was reduced, in order to maintain its reflectance status (Silva et al., 2019b), using the PEM-P20 knapsack power sprayer (Kawashima, Changhua Hsien, Taiwan) with a flow rate of $2.9 \mathrm{~L}$ per min and pressure of 450 $\mathrm{KPa}$. Film reflectance capacity was measured by $\mathrm{L}^{*}$ values, immediately after the application and drying of the film, on five leaves of the plant canopy, using the CR-400 digital colorimeter (Konica Minolta, Inc., Tokyo, Japan). This colorimeter shows values of $\mathrm{L}^{*}$ on a scale from 0 (total light absorption) to 100 (total light reflection), which is associated with the reflective properties of leaves and film residue. The $\mathrm{L}^{*}$ values from the particle film at each concentration were compared with those of the control (water), allowing to identify variation in luminosity related to residual film persistence or removal due to climate conditions such as rainfall (Silva et al., 2019b).

The Ourinho sweet potato cultivar was used. Branches with four to eight knots were obtained from crops cultivated in the municipality of Itabaiana, in the state of Sergipe, and $50 \%$ of them were buried in pits for cultivation.

Irrigation was performed with drippers, and the amount of water applied was calculated based on the crop evapotranspiration values informed by a local weather station. Fertilization was carried out using: 20 $\mathrm{kg} \mathrm{ha}{ }^{-1} \mathrm{~N}, 90 \mathrm{~kg} \mathrm{ha}^{-1} \mathrm{P}_{2} \mathrm{O}_{5}$, and $90 \mathrm{~kg} \mathrm{ha}^{-1} \mathrm{~K}_{2} \mathrm{O}$ during planting; and $30 \mathrm{~kg} \mathrm{ha}^{-1} \mathrm{~N}, 40 \mathrm{~kg} \mathrm{ha}^{-1} \mathrm{P}_{2} \mathrm{O}_{5}$, and $60 \mathrm{~kg} \mathrm{ha}^{-1}$ $\mathrm{K}_{2} \mathrm{O} 30$ DAP.

During the experimental period, the climatic conditions were monitored by collecting information from a meteorological station installed in the experimental area (Figure 1).

Nondestructive measurements of the Falker chlorophyll $a$ ( $\mathrm{Clh}$ a) and chlorophyll $b$ ( $\mathrm{Clh}$ b) indices, as well as total chlorophyll ( $\mathrm{Clh} \mathrm{a}+\mathrm{Clh}$ b), were calculated. The nondestructive CFL1030 Falker chlorophyll index meter (Falker Automação Agrícola Ltda., Porto Alegre, RS, Brazil) was used. The applied method is based on the absorbance of light emitted by diodes at three wavelengths: two red (635 and $660 \mathrm{~nm}$ ) and one infrared $(880 \mathrm{~nm})$. After crossing the leaf, the light was captured by silicon photodiodes transmitting the signals analogously. The equipment provided absorbance readings to estimate the chlorophyll $a$ and $b$ pool (Barbieri Junior et al., 2012; Cancellier et al., 2013; Schlichting et al., 2015).

The net photosynthetic rate $\left(A, \mu \mathrm{mol} \mathrm{CO}_{2} \mathrm{~m}^{-2} \mathrm{~s}^{-1}\right)$ was determined 30 days before harvest at 9:00 a.m. on healthy and physiologically active leaves in the middle third of the branches, using the LI-6400XT portable infrared gas-exchange analyzer (LI-COR Biosciences, Lincoln, NE, USA). The equipment was calibrated according to the local climate conditions at the time of measurement, with photosynthetic active radiation of
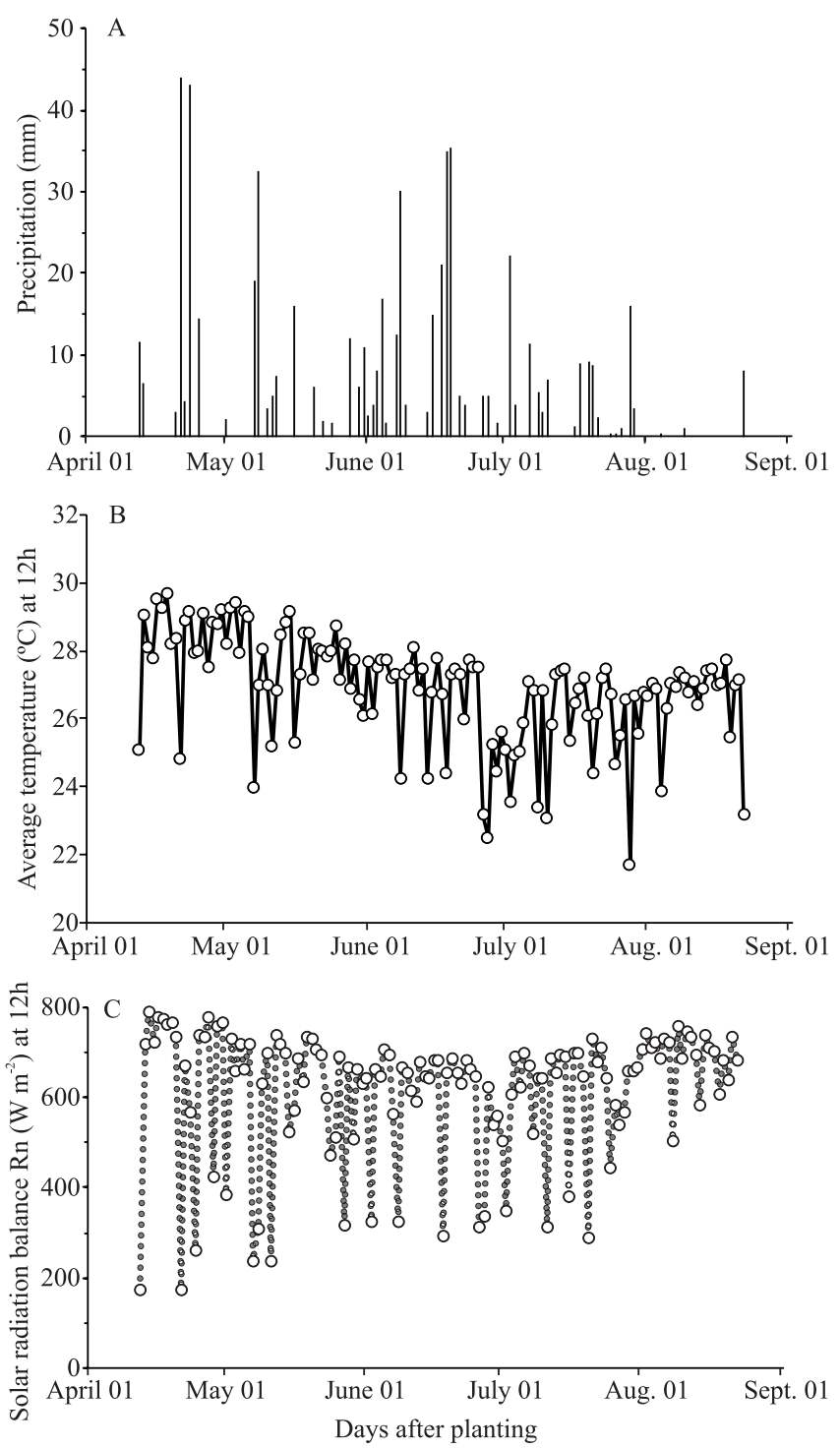

Figure 1. Daily cumulative precipitation (A), average temperature (B), and cumulative solar radiation (C) during the experimental period from April to September, 2018. 
$1,500 \mu \mathrm{mol} \mathrm{m} \mathrm{m}^{-2} \mathrm{~s}^{-1}$ and $\mathrm{CO}_{2}$ concentration of reference of $400 \pm 2 \mu \mathrm{mol} \mathrm{mol}^{-1}$.

Samples of sweet potato twigs were collected using a $0.23 \mathrm{~m}^{2}$ sampling frame, randomly allocated in each experimental unit. After collection, the samples were identified, weighed, and stored in plastic bags. Then, a subsample composed of branches(leaves and stalks)was removed and put into paper bags, identified, weighed, and dried in a forced-air ventilation oven at $55^{\circ} \mathrm{C}$ for 72 hours to obtain dry weight. Total productivity was determined by summing the accumulations (megagram per hectare) at each collection.

Total root productivity was obtained by selecting, from each plot, all tuber roots at harvest. Total weight was extrapolated to $\mathrm{Mg} \mathrm{ha}^{-1}$.

Before the bromatological composition analyses, the pre-dried branch samples were ground in a Willey type mill with a $1 \mathrm{~mm}$ sieve, identified, and stored in plastic bags. Subsequently, the analyses of dry matter (DM), crude protein (CP), neutral detergent fiber (NDF), acid detergent fiber (ADF), lignin, ether extract (EE), and ash were performed according to the methodology described by Zenebon et al. (2008). Total carbohydrates (CHOT) and nonfibrous carbohydrates (CNF) were estimated through the equations in Sniffen et al. (1992): $\mathrm{CHOT}=100 \%-(\mathrm{CP} \%+\mathrm{EE} \%+\mathrm{ASH} \%)$ and $\mathrm{CNF}=\mathrm{CHOT}-\mathrm{NDF} \%$. Total digestible nutrients (TDN) were determined according to Cappelle et al. (2001), using the equation: TDN $=83.79-(0.4171 \times \% \mathrm{NDF})$. Dry matter digestibility (DMD) was estimated as in Castro Filho et al. (2007), by the equation: $\mathrm{DMD}=88.9-(0.799 \times$ ADF\%). Additionally, crude protein production per hectare was calculated by multiplying the total accumulation by the crude protein content $\left(\mathrm{Mg} \mathrm{ha}^{-1}\right)$.

The obtained data were subjected to the analysis of variance using the $\mathrm{R}$ software (Bhering, 2017; R Core Team, 2017), and means were compared by Tukey's test, at $5 \%$ probability.

\section{Results and Discussion}

Sweet potato $A$, root productivity, and shoot increased with the application of the $\mathrm{CaO}$ particle film. Higher $A$ values of 35.67 and $32.02 \mu \mathrm{mol} \mathrm{CO}_{2}$ $\mathrm{m}^{-2} \mathrm{~s}^{-1}$, respectively, were obtained at 10 and $15 \% \mathrm{CaO}$ (Figure 2). For the control and $5 \% \mathrm{CaO}, A$ values were lower: 16.92 and $22.57 \mu \mathrm{mol} \mathrm{CO}_{2} \mathrm{~m}^{-2} \mathrm{~s}^{-1}$, respectively.
In general, the growth habit and chemical composition of plants are modified due to variations in the environment. These changes can range from increased or reduced photosynthetic rate and chlorophyll content, directly interfering in productivity. In the present work, the use of 10 and $15 \% \mathrm{CaO}$ particle film doubled the photosynthetic rates of the sweet potato plants, compared with the control treatment (Figure 2). This increase is related to the protective effect of particle film on leaves, mitigating light stress (Rosati et al., 2006; Glenn et al., 2001, 2003). A similar effect was also observed in other species treated with particle films such as coffee (Coffea canephora Pierre ex A.Froehner) (Silva et al., 2019b), cowpea [Vigna unguiculata (L.) Walp.] (Oliveira Júnior et al., 2019), and grapevine (Vitis vinifera L.) (Dinis et al., 2018).

Root productivity was of 32.86 and $32.02 \mathrm{Mg} \mathrm{ha}^{-1}$ for 10 and $15 \% \mathrm{CaO}$, respectively, higher than that of 21.54 $\mathrm{Mg} \mathrm{ha}^{-1}$ for the control and of $20.25 \mathrm{Mg} \mathrm{ha}^{-1}$ for $5 \% \mathrm{CaO}$ (Figure 2). For shoot productivity, the highest value of $12.13 \mathrm{Mg} \mathrm{ha}^{-1}$ was recorded at $15 \% \mathrm{CaO}$, intermediate values of 10.40 and $9.0 \mathrm{Mg} \mathrm{ha}^{-1}$, respectively, were found at 5 and $10 \% \mathrm{CaO}$, and the lowest value of 7.73 $\mathrm{Mg} \mathrm{ha}^{-1}$ was obtained for the control.

With the increase of the photosynthetic rate at 10 and $15 \% \mathrm{CaO}$, a higher yield was observed for sweet potato aerial part and roots. The increase in root productivity, especially for plants treated with $10 \% \mathrm{CaO}$, is related to the higher photosynthetic rate achieved in this treatment. The root yield of the present experiment

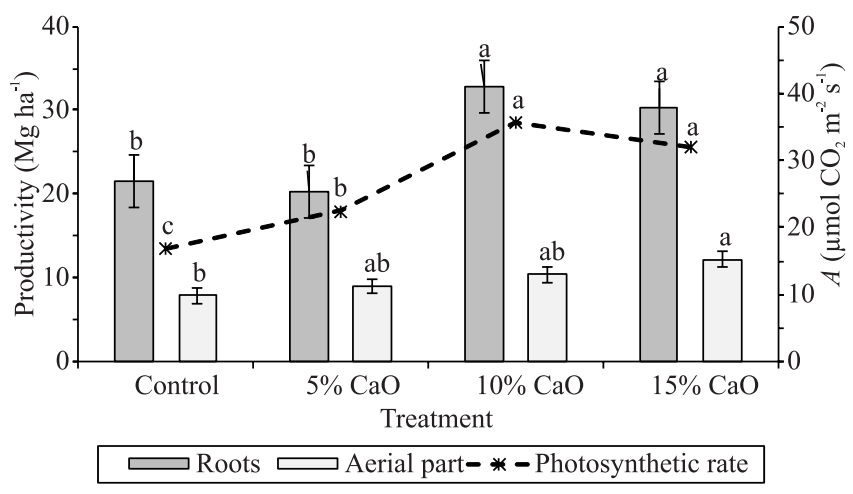

Figure 2. Root, aerial part, and net photosynthesis productivity $(A)$ of sweet potato (Ipomoea batatas) subjected to different concentrations of calcium oxide particle film. Means followed by equal letters do not differ by Tukey's test, at $5 \%$ probability. 
was higher than that found by Andrade Júnior et al. (2012), Azevedo et al. (2014), and Alves et al. (2017). Regarding shoot productivity, the values found were superior to those of 4.82 to $7.88 \mathrm{Mg} \mathrm{ha}^{-1}$ reported by Viana et al. (2011) when evaluating the yield of branches of different sweet potato cultivars after 150 days of cultivation.

The use of different particle film concentrations affected the total FCI and crude protein content. A higher total FCI of 45.93 was recorded in plants treated with $15 \% \mathrm{CaO}$ (Figure 3). Intermediate values of 41.93 and 37.03 total FCI, respectively, were obtained at 10 and $5 \%$ $\mathrm{CaO}$, while the lowest value of 35.48 was recorded for the control (Figure 3). A crude protein content of $12.8 \%$ was found at $15 \% \mathrm{CaO}$, higher than those of 10.1 and $10.8 \%$, respectively, for the control and $10 \% \mathrm{CaO}$; the lowest value of $7.9 \%$ was obtained at $5 \% \mathrm{CaO}$.

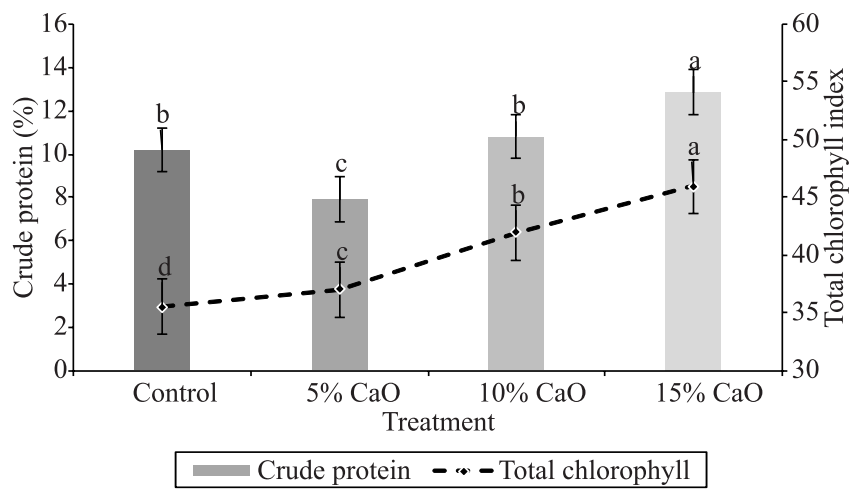

Figure 3. Crude protein content and total chlorophyll index of sweet potato (Ipomoea batatas) subjected to different concentrations of calcium oxide particle film. Means followed by equal letters do not differ by Tukey's test, at $5 \%$ probability.
Another effect of the particle film was observed regarding chlorophyll content and the bromatological composition of sweet potato twigs (Figure 3 and Table 1). The total FCI showed a linear tendency, increasing as the concentration of the particle film increased, and $15 \% \mathrm{CaO}$ reached the highest value compared with the other treatments $(15 \% \mathrm{CaO}>10 \%$ $\mathrm{CaO}>5 \% \mathrm{CaO}>$ control) (Figure 3). The increase in total chlorophyll content under the artificial shading promoted by particle films has been reported as being a physiological response to increasing light uptake (Ilić et al., 2015; Sano et al., 2018; Stagnari et al., 2018). Furthermore, chlorophyll content is related to protein content, which, in turn, is related to cell wall thickening. Some studies have shown that the use of Kaolin-based particle film reduces leaf density and thickness, mostly because it reduces the thickness of the upper palisade parenchyma, which, consequently, reduces the palisade/spongy parenchyma ratio, forming a less compact arrangement of mesophilic cells (Bacelar et al., 2009; Segura-Monroy et al., 2015; Brito et al., 2018, 2019b). The relationship between cell wall thickness and leaf chemical composition is responsible for the suitability of the sweet potato crop for dual use (tuberous root for human consumption and aerial part for animal feed), mainly due to the high protein content in the shoot of the species.

The highest crude protein contents were recorded at $15 \% \mathrm{CaO}$ (Figure 3), attributed to the higher coating of sweet potato twigs by the particle film, which may be compared with the chlorophyll data. Despite the lower concentration of crude protein content in the control and in the 5 and $10 \% \mathrm{CaO}$ treatments, it was observed that the obtained values remained above $7 \%$, the minimum required for the maintenance of rumen

Table 1. Bromatological composition of the aerial part of sweet potato (Ipomoea batatas) subjected to different concentrations of calcium oxide $(\mathrm{CaO})$ particle film.

\begin{tabular}{|c|c|c|c|c|c|}
\hline \multirow{2}{*}{$\begin{array}{l}\text { Variable } \\
(\%)\end{array}$} & \multicolumn{4}{|c|}{ Treatment $^{(1)}$} & \multirow{2}{*}{$\begin{array}{l}\text { Coefficient o } \\
\text { variation }(\%)\end{array}$} \\
\hline & $0 \% \mathrm{CaO}$ & $5 \% \mathrm{CaO}$ & $10 \% \mathrm{CaO}$ & $15 \% \mathrm{CaO}$ & \\
\hline Neutral detergent fiber & $45.08 \mathrm{ab}$ & $47.51 \mathrm{a}$ & $42.25 \mathrm{~b}$ & $43.31 \mathrm{~b}$ & 2.72 \\
\hline Acid detergent fiber & $37.40 \mathrm{a}$ & $38.13 \mathrm{a}$ & $32.62 b$ & $33.79 \mathrm{~b}$ & 2.49 \\
\hline Total carbohydrates & $77.75 b$ & $80.03 \mathrm{a}$ & $77.11 \mathrm{~b}$ & $75.06 \mathrm{c}$ & 0.86 \\
\hline Total digestible nutrients & $64.98 \mathrm{ab}$ & $63.97 \mathrm{~b}$ & $66.16 \mathrm{a}$ & $65.72 \mathrm{a}$ & 0.77 \\
\hline Dry matter digestibility & $59.75 b$ & $59.19 b$ & $63.48 \mathrm{a}$ & $62.57 \mathrm{a}$ & 1.13 \\
\hline Level of significance & $*$ & $*$ & $*$ & $*$ & \\
\hline
\end{tabular}

${ }^{(1)}$ Means followed by equal letters do not differ by Tukey's test, at 5\% probability. 
microbiota (Van Soest, 1994), as also observed by Corrêa et al. (2016) when evaluating silage from sweet potato branches.

The application of the $\mathrm{CaO}$ particle film influenced the bromatological composition of sweet potato. The films modified fiber content, where a higher NDF value was obtained at $5 \% \mathrm{CaO}$, followed by the control and 10 and $15 \% \mathrm{CaO}$. For $\mathrm{ADF}$, higher values were found for the control and 5\% $\mathrm{CaO}$, compared with 10 and $15 \% \mathrm{CaO}$ (Table 1).

The use of 10 and $15 \%$ particle film concentrations reduced the fiber content (NDF and ADF) of sweet potato twigs (Table 1). Therefore, the aerial part of the plant had a better chemical composition, with higher levels of crude protein (Figure 3). The fiber content is a determinant factor for animal consumption, as it is directly related to rumen filling, since a high fiber content hinders digestion by ruminal microorganisms in the digestible tract of ruminants, reducing the nutritional quality of the forage (Figueiredo et al., 2012). According to Nussio et al. (2006), for NDF, the minimum content should be between 30 and $60 \%$, and, for ADF, between 19 and $30 \%$, depending on the animal category.

CHOT levels also differed among treatments, with higher values obtained at $5 \% \mathrm{CaO}$, followed by the control and $10 \% \mathrm{CaO}$. The branches subjected to the application of $15 \% \mathrm{CaO}$ showed a lower CHOT content (Table 1).

Higher TDN contents were obtained with the 10 and $15 \% \mathrm{CaO}$ particle film, compared with the control and $5 \% \mathrm{CaO}$ (Table 1). Furthermore, DMD was also higher for plants at 10 and $15 \% \mathrm{CaO}$, and lower for the control and $5 \% \mathrm{CaO}$.

A higher and a lower crude protein and fiber content, respectively, provided a higher estimate of TDN and DMD (Table 1) of sweet potato twigs for the treatments with concentrations of 10 and $15 \% \mathrm{CaO}$, compared with the control and $5 \% \mathrm{CaO}$. In general, as the level of TDN and DMD increases, the availability of nutrients to be digested also increases (Velásquez et al., 2010; Oliveira et al., 2015).

The use of the particle film at the concentrations of 10 and $15 \% \mathrm{CaO}$ allowed the increase of the photosynthetic rate, directly and positively influencing the productivity of the tuberous roots and aerial part of the crop (Figure 2). In addition, a better coverage of sweet potato twigs due to the use of particle film influenced cell wall structure, increasing chlorophyll and crude protein contents (Figure 3). Therefore, the use of particle film at those concentrations resulted in younger branches with a lower fibrous content and a higher digestibility and TDN (Table 1). This information is essential because the aerial part (branches and leaves) of sweet potato is a less explored by-product. With the application of the particle film at 10 and $15 \% \mathrm{CaO}$, it becomes a product of good quality and low cost, ideal for feeding ruminants.

\section{Conclusions}

1. The photosynthetic rate and chlorophyll content of sweet potato (Ipomoea batatas) plants increase with the application of 10 and $15 \%$ calcium oxide $(\mathrm{CaO})$ particle film.

2. The application of 10 and $15 \% \mathrm{CaO}$ particle film increases sweet potato productivity.

3. The concentrations of 10 and $15 \% \mathrm{CaO}$ contribute to the improvement of the bromatological quality of the aerial part of sweet potato.

\section{Acknowledgments}

To Coordenação de Aperfeiçoamento de Pessoal de Nível Superior (Capes), for partial financing (Finance Code 001); to Conselho Nacional de Desenvolvimento Científico e Tecnológico (CNPq) and to Fundação de Apoio à Pesquisa e à Inovação Tecnológica do Estado de Sergipe (Fapitec), for financial support.

\section{References}

AKOETEY, W.; BRITAIN, M.M.; MORAWICKI, R.O. Potential use of byproducts from cultivation and processing of sweet potatoes. Ciência Rural, v.47, e20160610, 2017. DOI: https://doi.org/10.1590/0103-8478cr20160610.

ALVES, R.P.; BLANK, A.F.; OLIVEIRA, A.M.S.; SANTANA, A.D.D.; PINTO, V.S.; ANDRADE, T.M. Morpho-agronomic characterization of sweet potato germplasm. Horticultura Brasileira, v.35, p.534-541, 2017. DOI: https://doi.org/10.1590/ s0102-053620170410.

ANDRADE JÚNIOR, V.C. de; VIANA, D.J.S.; PINTO, N.A.V.D.; RIBEIRO, K.G.; PEREIRA, R.C.; NEIVA, I.P.; AZEVEDO, A.M.; ANDRADE, P.C. de R. Características produtivas e qualitativas de ramas e raízes de batata-doce. Horticultura Brasileira, v.30, p.584-589, 2012. DOI: https://doi.org/10.1590/ S0102-05362012000400004.

AREGHEORE, E.M. Nutritive value of sweet potato (Ipomea batatas (L) Lam) forage as goat feed: voluntary intake, growth and digestibility of mixed rations of sweet potato and batiki grass (Ischaemum aristatum var. indicum). Small Ruminant 
Research, v.51, p.235-241, 2004. DOI: https://doi.org/10.1016/ S0921-4488(03)00198-6.

AZEVEDO, A.M.; ANDRADE JÚNIOR, V.C.; VIANA, D.J.S.; ELSAYED, A.Y.; PEDROSA, C.E.; NEIVA, I.P.; FIGUEIREDO, J.A. Influence of harvest time and cultivation sites on the productivity and quality of sweet potato. Horticultura Brasileira, v.32, p.21-27, 2014. DOI: https://doi.org/10.1590/ S0102-05362014000100004.

BACELAR, E.A.; MOUTINHO-PEREIRA, J.M.; GONÇALVES, B.C.; LOPES, J.I.; CORREIA, C.M. Physiological responses of different olive genotypes to drought conditions. Acta Physiologiae Plantarum, v.31, p.611-621, 2009. DOI: https://doi.org/10.1007/s11738-009-0272-9.

BACKER, J.; RUIZ, M.E.; MUNOZ, H.; PINCHINAT, A.M. The use of sweet potato (Ipomoea batatas, (L) Lam) in animal feeding. II Beef production. Tropical Animal Health and Production, v.5, p.152-160, 1980.

BARBIERI JUNIOR, É.; ROSSIELLO, R.O.P.; SILVA, R.V.M.M.; RIBEIRO, R.C.; MORENZ, M.J.F. Um novo clorofilômetro para estimar os teores de clorofila em folhas do capim Tifton 85. Ciência Rural, v.42, p.2242-2245, 2012. DOI: https://doi.org/10.1590/S0103-84782012005000109.

BHERING, L.L. Rbio: a tool for biometric and statistical analysis using the $\mathrm{R}$ platform. Crop Breeding and Applied Biotechnology, v.17, p.187-190, 2017. DOI: https://doi.org/10.1590/1984-70332017v17n2s29.

BRITO, C.; DINIS, L.-T.; FERREIRA, H.; ROCHA, L.; PAVIA, I.; MOUTINHO-PEREIRA, J.; CORREIA, C.M. Kaolin particle film modulates morphological, physiological and biochemical olive tree responses to drought and rewatering. Plant Physiology and Biochemistry, v.133, p.29-39, 2018. DOI: https://doi.org/10.1016/j.plaphy.2018.10.028.

BRITO, C.; DINIS, L.-T.; MOUTINHO-PEREIRA, J.; CORREIA, C. Kaolin, an emerging tool to alleviate the effects of abiotic stresses on crop performance. Scientia Horticulturae, v.250, p.310-316, 2019a. DOI: https://doi.org/10.1016/j. scienta.2019.02.070.

BRITO, C.; DINIS, L.-T.; LUZIO, A.; SILVA, E.; GONÇALVES, A.; MEIJÓN, M.; ESCANDÓN, M.; ARROBAS, M.; RODRIGUES, M.Â.; MOUTINHO-PEREIRA, J.; CORREIA, C.M. Kaolin and salicylic acid alleviate summer stress in rainfed olive orchards by modulation of distinct physiological and biochemical responses. Scientia Horticulturae, v.246, p.201-211, 2019b. DOI: https://doi.org/10.1016/j.scienta.2018.10.059.

CANCELLIER, E.L.; SILVA, J.; SANTOS, M.M. dos; SIEBENEICHLER. S.C.; FIDELIS, R.R. Índices de clorofila em partes da planta de arroz de terras altas. Revista Verde de Agroecologia e Desenvolvimento Sustentável, v.8, p.199-206, 2013.

CAPPELLE, E.R.; VALADARES FILHO, S. de C.; SILVA, J.F.C. da; CECON, P.R. Estimativas do valor energético a partir de características químicas e bromatológicas dos alimentos. Revista Brasileira Zootecnia, v.30, p.1837-1856, 2001. DOI: https://doi.org/10.1590/S1516-35982001000700022.

CASTRO FILHO, M.A.; BARBOSA, M.A.A.F.; OLIVEIRA, R.L.; BAGALDO, A.R.; GASTAL, D.W. Valor nutritivo da palha de milho verde para bovinos. Revista Brasileira de Saúde e Produção Animal, v.8, p.112-121, 2007.

CORRÊA, A.A.; BACKES, A.A.; FAGUNDES, J.L.; BARBOSA, L.T.; SOUSA, B.M.L.; OLIVEIRA, V.S.; MOREIRA, A.L. Caracterização da silagem da rama da batata doce emurchecida e adicionada de fubá de milho como aditivo. Boletim de Indústria Animal, v.73, p.272-280, 2016. DOI: https://doi.org/10.17523/bia. v73n4p272.

DELAZARI, F.T.; FERREIRA, M.G.; SILVA, G.H. da; DARIVA, F.D.; FREITAS, D.S. de; NICK, C. Eficiência no uso da água e acúmulo de matéria na batata-doce em função de lâminas de irrigação. Irriga, v.22, p.115-128, 2017. DOI: https://doi.org/10.15809/irriga.2017v22n1p115-128.

DINIS, L.-T.; BERNARDO, S.; LUZIO, A.; PINTO, G.; MEIJÓN, M.; PINTÓ-MARIJUAN, M.; COTADO, A.; CORREIA, C.; MOUTINHO-PEREIRA, J. Kaolin modulates ABA and IAA dynamics and physiology of grapevine under Mediterranean summer stress. Journal of Plant Physiology, v.220, p.181-192, 2018. DOI: https://doi.org/10.1016/j.jplph.2017.11.007.

DRAPAL, M.; ROSSEL, G.; HEIDER, B.; FRASER, P.D. Metabolic diversity in sweet potato (Ipomoea batatas, Lam.) leaves and storage roots. Horticulture Research, v.6, art.2, 2019. DOI: https://doi.org/10.1038/s41438-018-0075-5.

FIGUEIREDO, J.A.; ANDRADE JÚNIOR, V.C. de; PEREIRA, R.C.; RIBEIRO, K.G.; VIANA, D.J.S.; NEIVA, I.P. Avaliação de silagens de ramas de batata-doce. Horticultura Brasileira, v.30, p.708-712, 2012. DOI: https://doi.org/10.1590/S010205362012000400024.

GLENN, D.M.; PUTERKA, G.J.; DRAKE, S.R.; UNRUH, T.R.; KNIGHT, A.L.; BAHERLE, P.; PRADO, E.; BAUGHER, T.A. Particle film application influences apple leaf physiology, fruit yield, and fruit quality. Journal of the American Society for Horticultural Science, v.126, p.175-181, 2001. DOI: https://doi.org/10.21273/JASHS.126.2.175.

GLENN, D.M.; EREZ, A.; PUTERKA, G.J.; GUNDRUM, P. Particle films affect carbon assimilation and yield in 'Empire' apple. Journal of the American Society for Horticultural Science, v.128, p.356-362, 2003. DOI: https://doi.org/10.21273/ JASHS.128.3.0356.

ILIĆ, Z.S.; MILENKOVIĆ, L.; ŠUNIĆ, L.; FALLIK, E. Effect of coloured shade-nets on plant leaf parameters and tomato fruit quality. Journal of the Science of Food and Agriculture, v.95, p.2660-2667, 2015. DOI: https://doi.org/10.1002/jsfa.7000.

MONTEIRO, A.B.; MASSAROTO, J.A.; GASPARINO, C.F.; SILVA, R.R.; GOMES, L.A.A.; MALUF, W.R.; FILHO, J.C.S. Silagens de cultivares e clones de batata doce para alimentação animal visando sustentabilidade da produção agrícola familiar. Revista Brasileira de Agroecologia, v.2, p.978-981, 2007.

NUSSIO, L.G.; CAMPOS, F.P. de; LIMA, M.L.M. de. Estratégia do metabolismo de carboidratos estruturais. In: BERCHIELLI, T.T.; PIRES, A.V.; OLIVEIRA, S.G. (Ed.). Nutrição de ruminantes. Jaboticabal: Funep, 2006. v.1, cap. 7, p.183-223.

OLIVEIRA JÚNIOR, L.F.G. de; SANTOS, P.L. de S.; LIMA, R.S.N. de; SILVEIRA, M.P.C.; FAGUNDES, J.L.; CARNELOSSI, M.A.G.; REIS, F. de O. Physiological parameters of cowpea treated 
with $\mathrm{CaO}$-based particle film and subjected to water restriction. Pesquisa Agropecuária Brasileira, v.54, e00033, 2019. DOI: https://doi.org/10.1590/S1678-3921.pab2019.v54.00033.

OLIVEIRA, F.C.C.; PEDROTTI, A.; FELIX, A.G.S.; SOUZA, J.L.S.; HOLANDA, F.S.R.; MELLO JUNIOR, A.V. Características químicas de um Argissolo e a produção de milho verde nos Tabuleiros Costeiros sergipanos. Revista Brasileira de Ciências Agrárias, v.12, p.354-360, 2017. DOI: https://doi.org/10.5039/agraria.v12i3a5464.

OLIVEIRA, V.S.; MORAIS, J.A. da S.; FAGUNDES, J.L.; SANTANA, J.C. dos S.; LIMA, I.G.S.; SANTOS, C.B. Produção e composição químico-bromatológica de gramíneas tropicais submetidas a dois níveis de irrigação. Archives of Veterinary Science, v.20, p.27-36, 2015. DOI: https://doi.org/10.5380/avs. v20i2.36337.

R CORE TEAM. R: a language and environment for statistical computing. Vienna: R Foundation for Statistical Computing, 2017. Available at: $<$ https//www.r-project.org/>. Accessed on: Jan. 282020.

RAVI, V.; SARAVANAN, R. Crop physiology of sweetpotato. Fruit, Vegetable and Cereal Science and Biotechnology, v.6, p.17-29, 2012.

ROSATI, A.; METCALF, S.G.; BUCHNER, R.P.; FULTON, A.E.; LAMPINEN, B.D. Physiological effects of kaolin applications in well-irrigated and water-stressed walnut and almond trees. Annals of Botany, v.98, p.267-275, 2006. DOI: https://doi.org/10.1093/aob/mcl100.

SANO, T.; HORIE, H.; MATSUNAGA, A.; HIRONO, Y. Effect of shading intensity on morphological and color traits and on chemical components of new tea (Camellia sinensis L.) shoots under direct covering cultivation. Journal of the Science of Food and Agriculture, v.98, p.5666-5676, 2018. DOI: https://doi.org/10.1002/jsfa.9112.

SANTOS, H.G. dos; JACOMINE, P.K.T.; ANJOS, L.H.C. dos; OLIVEIRA, V.Á. de; LUMBRERAS, J.F.; COELHO, M.R.; ALMEIDA, J.A. de; ARAÚJO FILHO, J.C. de; OLIVEIRA, J.B. de; CUNHA, T.J.F. Sistema brasileiro de classificação de solos. 5.ed. rev. e ampl. Brasília: Embrapa, 2018. 356p.

SANTOS, V.P. dos; FERNANDES, P.D.; MELO, A.S. de; SOBRAL, L.F.; BRITO, M.E.B.; DANTAS, J.D. de M.; BONFIM, L.V. Fertirrigação da bananeira cv. Prata-Anã com N e K em um Argissolo Vermelho-Amarelo. Revista Brasileira de Fruticultura, v.31, p.567-573, 2009. DOI: https://doi.org/10.1590/ S0100-29452009000200035.

SCHLICHTING, A.F.; BONFIM-SILVA, E.M.; SILVA, M. de C.; PIETRO-SOUZA, W; SILVA, T.J.A. da; FARIAS, L. do N. Efficiency of portable chlorophyll meters in assessing the nutritional status of wheat plants. Revista Brasileira de Engenharia Agrícola e Ambiental, v.19, p.1148-1151, 2015. DOI: https://doi.org/10.1590/1807-1929/agriambi.v19n12p1148-1151.

SEGURA-MONROY, S.; URIBE-VALLEJO, A.; RAMIREZGODOY, A.; RESTREPO-DIAZ, H. Effect of kaolin application on growth, water use efficiency, and leaf epidermis characteristics of Physalis peruviana L. seedlings under two irrigation regimes.
Journal of Agricultural Science and Technology, v.17, p.15851596, 2015.

SILVA, L.F.L. e; GONÇALVES, W.M.; MALUF, W.R.; RESENDE, L.V.; LASMAR, A.; CARVALHO, R. de C.; LICURSI, V.; MORETTO, P. Energy and budget balances for sweet potato-based ethanol production. Pesquisa Agropecuária Brasileira, v.54, e26521, 2019a. DOI: https://doi.org/10.1590/ S1678-3921.pab2019.v54.26521.

SILVA, P.S.O. da; OLIVEIRA JUNIOR, L.F.G.; GONZAGA, M.I.S.; SENA, E. de O.A.; MACIEL, L.B. dos S.; FIAES, M.P.; MATTOS, E.C de.; CARNELOSSI, M.A.G. Effects of calcium particle films and natural shading on ecophysiological parameters of conilon coffee. Scientia Horticulturae, v.245, p.171-177, 2019b. DOI: https://doi.org/10.1016/j.scienta.2018.10.010.

SNIFFEN, C.J.; O'CONNOR, J.D.; VAN SOEST, P.J.; FOX, D.G.; RUSSEL, J.B. A net carbohydrate and protein system for evaluating cattle diets: II. Carbohydrate and protein availability. Journal of Animal Science, v.70, p.3562-3577, 1992. DOI: https://doi.org/10.2527/1992.70113562x.

SOIL SURVEY STAFF. Soil taxonomy: a basic system of soil classification for making and interpreting soil surveys. $2^{\text {nd }}$ ed. Washington: Usda, Natural Resources Conservation Service, 1999. 866p. (Agriculture Handbook, n.436).

STAGNARI, F.; DI MATTIA, C.; GALIENI, A.; SANTARELLI, V.; D'EGIDIO, S.; PAGNANI, G.; PISANTE, M. Light quantity and quality supplies sharply affect growth, morphological, physiological and quality traits of basil. Industrial Crops and Products, v.122, p.277-289, 2018. DOI: https://doi.org/10.1016/j. indcrop.2018.05.073.

THIBODEAU, M.S.; POORE, M.H.; ROGERS, G.M. Health and production aspects of feeding sweetpotato to cattle. Veterinary Clinics of North America: Food Animal Practice, v.18, p.349365, 2002. DOI: https://doi.org/10.1016/s0749-0720(02)00022-1.

VAN SOEST, P.J. Nutritional ecology of the ruminant. $2^{\text {nd }}$ ed. Ithaca: Cornell University Press, 1994. DOI: https://doi.org/10.7591/9781501732355.

VELÁSQUEZ, P.A.T.; BERCHIELLI, T.T.; REIS, R.A.; RIVERA, A.R.; DIAN, P.H.M.; TEIXEIRA, I.A.M. de A. Composição química, fracionamento de carboidratos e proteínas e digestibilidade in vitro de forrageiras tropicais em diferentes idades de corte. Revista Brasileira de Zootecnia, v.39, p.1206-1213, 2010. DOI: https://doi.org/10.1590/S151635982010000600007 .

VIANA, D.J.S.; ANDRADE JÚNIOR, V.C. de; RIBEIRO, K.G.; PINTO, N.A.V.D.; NEIVA, I.P.; FIGUEIREDO, J.A.; LEMOS, V.T.; PEDROSA, C.E.; AZEVEDO, A.M. Potencial de silagens de ramas de batata-doce para alimentação animal. Ciência Rural, v.41, p.1466-1471, 2011. DOI: https://doi.org/10.1590/S010384782011000800027.

ZENEBON, O.; PASCUET, N.S.; TIGLEA, P. (Coord.). Métodos físico-químicos para análise de alimentos. 4.ed., 1.ed. digital. São Paulo: Instituto Adolfo Lutz, 2008. 1020p. 